Article

\title{
Chronic Binge Alcohol Administration Dysregulates Hippocampal Genes Involved in Immunity and Neurogenesis in Simian Immunodeficiency Virus-Infected Macaques
}

\author{
John K. Maxi ${ }^{1}$, Matt Dean ${ }^{2}$, Jovanny Zabaleta ${ }^{3}$, Krzysztof Reiss ${ }^{3}$, Gregory J. Bagby ${ }^{1,4}$, \\ Steve Nelson ${ }^{4}$, Peter J. Winsauer ${ }^{4,5}$, Francesca Peruzzi ${ }^{6}$ and Patricia E. Molina ${ }^{1,4, *}$ \\ 1 Department of Physiology, Louisiana State University Health Sciences Center, New Orleans, LA 70112, USA; \\ jmaxi@lsuhsc.edu (J.K.M.); gbagby@lsuhsc.edu (G.J.B.) \\ 2 Department of Genetics, Louisiana State University Health Sciences Center, New Orleans, LA 70112, USA; \\ mdean3@1suhsc.edu \\ 3 Department of Pediatrics and Stanley S. Scott Cancer Center, Louisiana State University Health Sciences \\ Center, New Orleans, LA 70112, USA; jzabal@1suhsc.edu (J.Z.) kreiss@lsuhsc.edu (K.R.) \\ 4 Comprehensive Alcohol Research Center, Louisiana State University Health Sciences Center, New Orleans, \\ LA 70112, USA; snelso1@lsuhsc.edu (S.N.); pwinsa@lsuhsc.edu (P.J.W.) \\ 5 Department of Pharmacology and Experimental Therapeutics, Louisiana State University Health Sciences \\ Center, New Orleans, LA 70112, USA \\ 6 Department of Internal Medicine, Louisiana State University Health Sciences Center, New Orleans, \\ LA 70112, USA; fperuz@lsuhsc.edu \\ * Correspondence: pmolin@lsuhsc.edu; Tel.: +1-504-568-6181
}

Academic Editor: Natalia Osna

Received: 15 September 2016; Accepted: 28 October 2016; Published: 9 November 2016

\begin{abstract}
Alcohol use disorders (AUD) exacerbate neurocognitive dysfunction in Human Immunodeficiency Virus (HIV+) patients. We have shown that chronic binge alcohol (CBA) administration (13-14 g EtOH $/ \mathrm{kg} / \mathrm{wk}$ ) prior to and during simian immunodeficiency virus (SIV) infection in rhesus macaques unmasks learning deficits in operant learning and memory tasks. The underlying mechanisms of neurocognitive alterations due to alcohol and SIV are not known. This exploratory study examined the CBA-induced differential expression of hippocampal genes in SIV-infected (CBA/SIV $+; n=2)$ macaques in contrast to those of sucrose administered, SIV-infected (SUC/SIV+; $n=2)$ macaques. Transcriptomes of hippocampal samples dissected from brains obtained at necropsy (16 months post-SIV inoculation) were analyzed to determine differentially expressed genes. MetaCore from Thomson Reuters revealed enrichment of genes involved in inflammation, immune responses, and neurodevelopment. Functional relevance of these alterations was examined in vitro by exposing murine neural progenitor cells (NPCs) to ethanol (EtOH) and HIV trans-activator of transcription (Tat) protein. EtOH impaired NPC differentiation as indicated by decreased $\beta I I I$ tubulin expression. These findings suggest a role for neuroinflammation and neurogenesis in CBA/SIV neuropathogenesis and warrant further investigation of their potential contribution to CBA-mediated neurobehavioral deficits.
\end{abstract}

Keywords: SIV; alcohol; macaque; hippocampus; neural progenitor cells; Tat; microarray; neuroinflammation; neurogenesis 


\section{Introduction}

The lifetime history of alcohol use disorder (AUD) in persons living with Human Immunodeficiency Virus / Acquired Immune Deficiency Syndrome (HIV/AIDS) (PLWHA) is 55\%, compared to $12 \%-29 \%$ in the general population [1,2]. AUD in PLWHA accelerates disease progression and contributes to comorbid pathologies, including cognitive dysfunction, termed HIV-associated neurocognitive disorder (HAND) [3-5]. This disorder occurs in up to 50\% of PLWHA and is diagnosed when impairment is present in two or more cognitive domains (e.g., learning and memory, executive functioning, speed of information processing, motor skills, language) [6,7]. Joska et al. [3] demonstrated an interaction between alcohol use disorder and time from HIV diagnosis in the development of HAND. Moreover, history of alcohol dependence was associated with greater neurocognitive deficits in persons older than 60 [4].

Studies from our laboratory have demonstrated that chronic binge alcohol (CBA) administration in non-antiretroviral treated, simian immunodeficiency virus (SIV)-infected macaques increases viral load at set-point, increases muscle wasting, accelerates time to end-stage disease, and unmasks cognitive impairment as determined by an operant learning and memory task [8-12]. The operant learning and memory procedure required macaques to learn a sequence of lever presses daily and emit a previously learned sequence of lever presses to obtain food reinforcement. Our results found that SIV-infected animals receiving alcohol (CBA/SIV+) made more errors in these tasks than non-SIV-infected animals receiving alcohol (CBA/SIV-), SIV-infected animals (SIV+) and control animals (SIV-). Moreover, this was remarkable because these error-increasing effects were not evident on the days of the week when the CBA/SIV+ animals were not receiving alcohol. These types of operant tasks are associated with hippocampal function, an area of the brain shown to be negatively affected by both alcohol and HIV [13-15].

The underlying mechanisms by which CBA contributes to cognitive impairment in SIV-infected macaques are unknown. Studies utilizing an accelerated model of central nervous system (CNS) HIV disease in non-human primates indicate that inflammation correlates with CNS pathology [16-18]. Neuroinflammation also plays an important role in alcohol neuropathology [19]. We propose that the combination of chronic alcohol administration and HIV/SIV infection may exacerbate neuroinflammation and neuropathology. In order to explore potential mechanisms by which CBA may contribute to behavioral deficits, we performed microarray analysis of hippocampal tissue to determine differential patterns of gene expression in CBA/SIV+ macaques compared to SIV+ macaques. Based on the differential gene expression seen in the microarray, and the pathways enriched with a greater number of differentially expressed genes, we hypothesized that CBA impairs neural progenitor cell (NPC) differentiation.

NPCs are the source of new neuron and glial cells. These cells are found primarily in the subventricular zone and the hippocampus. We chose to further investigate the development process for several reasons: (1) the hippocampus is one of the primary sites of adult neurogenesis [20]; (2) alterations in adult neurogenesis have been linked to cognitive impairments [20,21]; (3) neuroinflammation alters neurogenesis [22-24]; and (4) experimentally impairing hippocampal neurogenesis results in learning and memory deficits [25-27]. Enhanced neuroinflammation, which is suggested by the microarray gene changes, alters neurogenesis. To further investigate one of the potential mechanisms of cognitive impairment suggested by the microarray analysis, we used an in vitro model to examine the impact of exposure to ethanol $(\mathrm{EtOH})$ and HIV viral protein (Tat) on NPC differentiation. These in vitro studies allowed us to examine the functional relevance of the alterations in genes involved in neurogenesis. Our results provide insight into the principal relevant mechanisms involved in CBA and SIV neuropathogenesis. 


\section{Results}

\subsection{Hippocampus and Cerebrospinal Fluid Viral Load}

Viral DNA, which reflects infected cells, was detectable in the brain tissue of one sucrose-administered SIV-infected animal (SUC/SIV+) and both CBA/SIV+ animals. Viral RNA, which indicates viral replication, was present in one CBA/SIV+ animal but none of the SUC/SIV+ animals. The cerebrospinal fluid (CSF) viral loads in both CBA/SIV+ animals were higher than the CSF viral loads from SUC/SIV+ animals (Table 1). Confirmation of SIV infection and peripheral viral data was previously published for these animals [10].

Table 1. Simian immunodeficiency virus (SIV) DNA and RNA copy numbers in hippocampal tissue isolated at necropsy and cerebrospinal fluid (CSF) seven months prior to necropsy. Copy numbers of SIV gag DNA and RNA were normalized to the amount of housekeeping gene, ribosomal protein S13 (RPS13), present and then compared with a standard curve of known SIV copy number. CSF and plasma viral load were normalized to volume of CSF and plasma, respectively. CSF and plasma viral load were taken seven months prior to necropsy, during the asymptomatic stage of infection. The limit of detection was 25 copies in the tissue samples and 100 copies in the CSF. SUC/SIV+: sucrose administered, SIV-infected; CBA/SIV+: chronic binge alcohol administered, SIV-infected.

\begin{tabular}{ccccc}
\hline & \multicolumn{4}{c}{ SIV DNA and RNA in Central Nervous System Compartments } \\
\hline & \multicolumn{2}{c}{ Viral Load in Hippocampal Tissue } & CSF Viral Load & Plasma Viral Load \\
\hline \multirow{2}{*}{ Animal ID } & DNA (SIV & RNA (SIV & RNA (SIV & RNA (SIV Copies/mL, \\
& Copies/1 $\times \mathbf{1 0}^{\mathbf{6}}$ Cells) & Copies/ $\boldsymbol{\mu g}$ RPS13) & Copies/mL) & Log Transformed) \\
\hline EK21 (SUC/SIV+) & $<25$ & $<25$ & $<100$ & 6.41 \\
EJ59 (SUC/SIV+) & 510 & $<25$ & 5705 & 5.97 \\
EN44 (CBA/SIV+) & 140 & $<25$ & 7560 & 5.59 \\
EN72 (CBA/SIV+) & 660 & 2267 & 112,000 & 5.79 \\
\hline
\end{tabular}

\subsection{Process Networks Enriched with Differentially Expressed Genes}

We determined the process networks of the differentially expressed genes using MetaCore from Thomson Reuters. These process networks identify categories and specific cellular and molecular functions of the differentially expressed genes. The top ten enriched network processes in hippocampi of CBA/SIV+ animals (Figure 1B) included several functions in the cytoskeleton, cell adhesion, and immune response categories. To complement the enrichment analysis, we also quantified the frequency of process categories (e.g., cytoskeleton, immune response) occurring in the top 100 processes in which the differentially expressed genes were classified. The total number of occurrences for each category (Figure 2) showed inflammation as the most numerous, with immune response processes also being relatively abundant. Notably, several processes within other categories were related to inflammation and immune response; specifically, "leukocyte chemotaxis", "platelet aggregation" (cell adhesion) and "G1-S interleukin regulation" (cell cycle), indicating that the changes in immune function may contribute to changes in the other processes. To investigate this further, we combined "inflammation" and "immune response" gene lists into a single category, which we labeled "immune response". We then determined the number of up- and down-regulated genes within this category (Figure 3). We found that there were significantly more up-regulated genes in this category than would be expected compared to the proportion of up-regulated genes detected in the microarray by chi-square test. The inflammation/immune response genes are shown in Table 2. Developmental, cell adhesion, and signal transduction process networks were the second most represented networks among all the top 100 processes. 
A
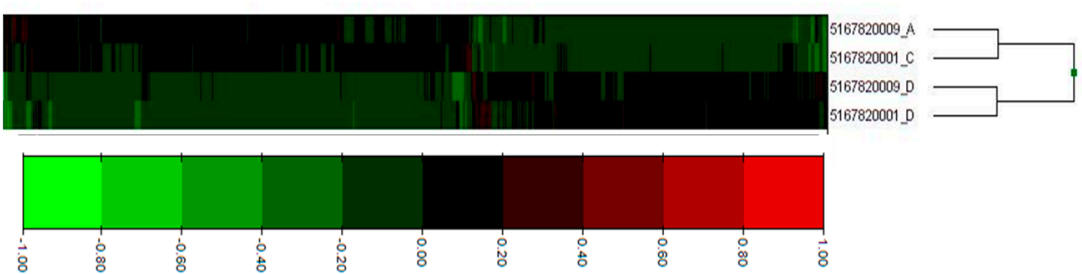

B

Top 10 Enriched Network Processes

Cell adhesion: Synaptic contact

Cell adhesion: Amyloid proteins

Cytoskeleton: Regulation of cytoskeleton rearrangement Cell adhesion: Integrin-mediated cell-matrix adhesion Immune response: Phagosome in antigen presentation Cytoskeleton: Spindle microtubules Immune response: Antigen presentation Reproduction: Feeding and Neurohormone signaling

Cell cycle: Mitosis

Cytoskeleton: Cytoplasmic microtubules

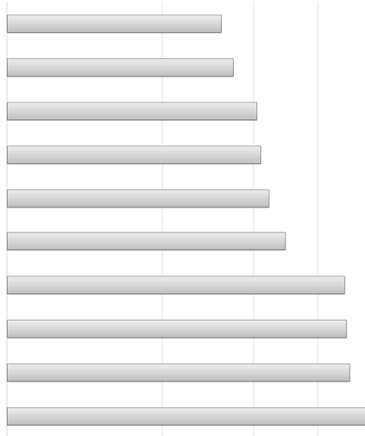

Figure 1. Heatmap of the differentially expressed genes in CBA/SIV+ and SUC/SIV+ used for MetaCore analysis and the top enriched process networks of those genes. (A) Heat map shows all 709 genes differentially expressed in CBA/SIV+ compared to SUC/SIV+. Differentially expressed genes were defined as the top one percent and bottom one percent of all genes detected in the microarray analysis. From those genes, only those in which both CBA/SIV+ animals had gene expression higher or lower than both SUC/SIV+ animals were used in process network analysis. Numbers 5167820009_D and 5167820001_D refer to SUC/SIV+ animals; (B) Top ten process networks enriched in differentially expressed genes in CBA/SIV compared to SUC/SIV macaques. Larger bars indicate greater significance.

\section{Cellular and molecular processes}

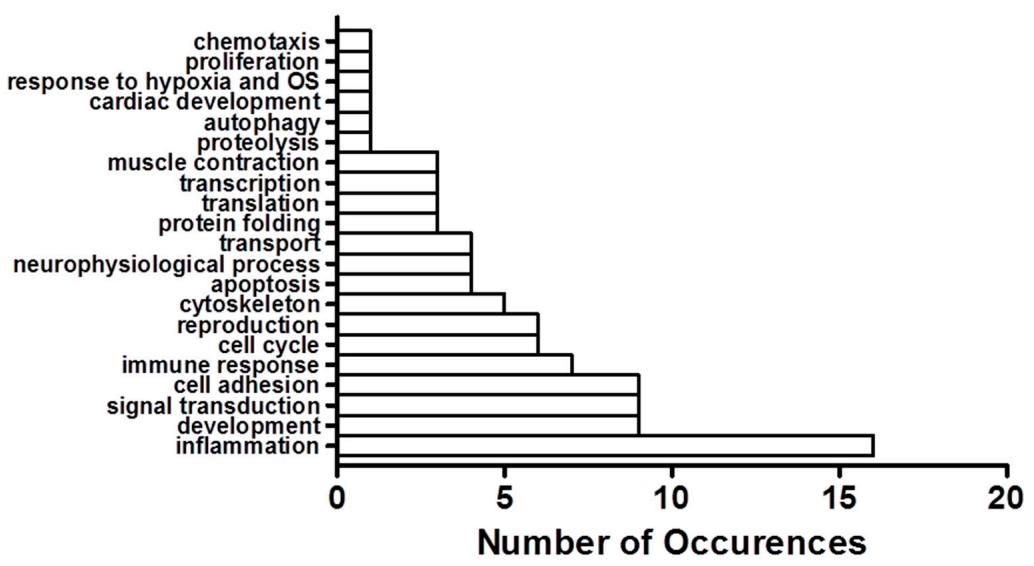

Figure 2. Number of occurrences in the top 100 specific process networks containing dysregulated $\mathrm{CBA} / \mathrm{SIV}+$ genes. The processes were classified using MetaCore nomenclature (e.g., the processes "inflammation complement system" and "inflammation IFN-gamma signaling" both count towards inflammation). The top 100 process networks containing differentially expressed genes were included in analysis. OS: oxidative stress; IFN: interferon. 


\section{Gene Expression Changes with Combined CBA and SIV}

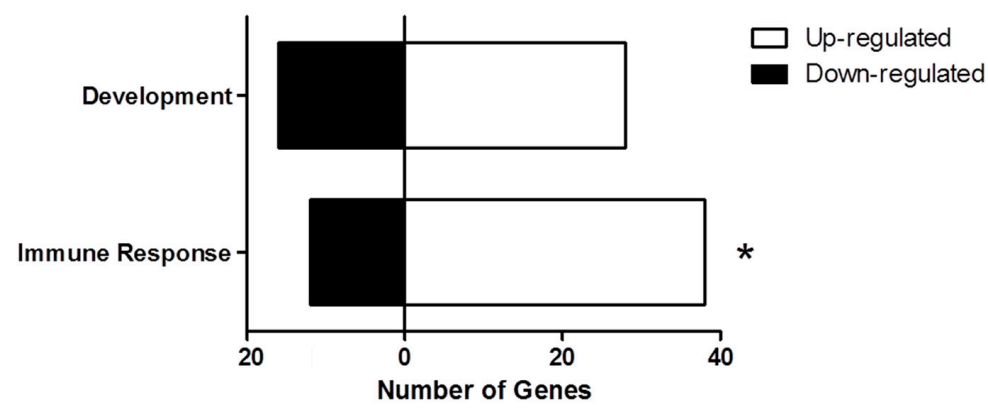

Figure 3. Number of genes involved in inflammatory and development processes that were up- and down-regulated. Immune processes include the set of genes from inflammation and immune response functions. The immune processes category had significantly more up-regulated genes than expected $(76 \%)$ compared to the total number of up-regulated genes out of all differentially expressed genes $(57 \%){ }^{*} p<0.01$, Chi-square test).

Table 2. Inflammation and immune response genes that are differentially expressed between CBA/SIV and SUC/SIV macaques. FC is the fold-change in gene expression between CBA/SIV and SUC/SIV macaques.

\begin{tabular}{|c|c|c|}
\hline \multicolumn{3}{|c|}{ Inflammation and Immune Response Associated Genes } \\
\hline Gene & Description & FC \\
\hline TXNIP & $\begin{array}{l}\text { Mediator of oxidative stress, over-expression induces G0/G1 cell cycle arrest, required for maturation of } \\
\text { NK cells }\end{array}$ & 2.43 \\
\hline CCL8 & Chemotactic factor for monocytes, lymphocytes, eosinophils, and basophils & 1.91 \\
\hline PROS1 & Anticoagulant plasma protein, stimulates fibrinolysis & 1.82 \\
\hline HLA-A & Presentation of antigens to the immune system, major histocompatibility class (MHC) I & 1.65 \\
\hline C1QC & Associates with $\mathrm{C} 1 \mathrm{r}$ and $\mathrm{C} 1 \mathrm{~s}$ to yield the first component of the complement system & 1.64 \\
\hline$C F B$ & $\begin{array}{l}\text { Complement Factor B, cleaved into Ba and Bb which further activate the complement cascade and } \\
\text { monocyte response, Ba inhibits proliferation of pre-activated B-lymphocytes }\end{array}$ & 1.60 \\
\hline$H L A-F$ & Presentation of antigens to the immune system, MHC class I & 1.58 \\
\hline HLA-G & Presentation of antigens to the immune system, MHC class I & 1.57 \\
\hline$H L A-D R A$ & $\begin{array}{l}\text { MHC class II-type, expressed by B lymphocytes, dendritic cells, and macrophages; presentation of } \\
\text { antigens to the immune system }\end{array}$ & 1.54 \\
\hline$H L A-H$ & Presentation of antigens to the immune system, MHC class I & 1.52 \\
\hline MSN & Moesin, cross-linker between plasma membrane and actin cytoskeleton, localized to filopodia & 1.52 \\
\hline APP & $\begin{array}{l}\text { Functions in neurite outgrowth, neuronal adhesion, and axogenesis. Cleavage products of APP activate } \\
\text { caspases and form amyloid plaques found in Alzheimer's. }\end{array}$ & 1.50 \\
\hline TFRC & Transferrin receptor, cellular uptake of iron, necessary for nervous system development & 1.50 \\
\hline ITPR1 & Intracellular inositol 1,4,5-triphosphate receptor, mediates release of $\mathrm{Ca}^{2+}$ from endoplasmic reticulum. & 1.46 \\
\hline MTOR & Mediates cellular responses to DNA damage and nutrient deprivation & 1.45 \\
\hline JAK1 & Kinase in interferon- $\alpha,-\beta$, and $-\gamma$ signal transduction pathways & 1.45 \\
\hline EDG1 & Role in cell migration & 1.45 \\
\hline HLA-E & Binds peptide-derived signal sequence of human leukocyte antigen (HLA) subtypes & 1.45 \\
\hline AP1G1 & Adaptin subunit, promotes formation of clathrin-coated vesicles for delivery from Golgi to lysosomes & 1.44 \\
\hline PIM1 & Proto-oncogene involved in cell survival, kinase activity suppresses pro-apoptotic proteins & 1.44 \\
\hline TNFRSF1A & $\begin{array}{l}\text { Tumor necrosis factor (TNF) receptor, activates nuclear factor kappa-light-chain-enhancer of activated B } \\
\text { cells (NFkB), apoptosis, and inflammation }\end{array}$ & 1.40 \\
\hline ELK1 & Stimulates transcription induced by mitogen-activated protein kinase (MAPK) signaling cascade & 1.39 \\
\hline PSMA6 & Peptidase that is a component of the $20 \mathrm{~S}$ subunit of the proteasome & 1.39 \\
\hline ODC1 & Important enzyme for polyamine synthesis, converts ornithine to putrescine & 1.38 \\
\hline NME1-NME2 & Naturally occurring read-through region between NME1-NME2 genes & 1.37 \\
\hline HLA-DPA1 & $\begin{array}{l}\text { MHC class II-type, expressed by B lymphocytes, dendritic cells, and macrophages; presentation of } \\
\text { antigens to the immune system }\end{array}$ & 1.37 \\
\hline GNG10 & G protein subunit gamma & 1.35 \\
\hline
\end{tabular}


Table 2. Cont.

\begin{tabular}{|c|c|c|}
\hline \multicolumn{3}{|c|}{ Inflammation and Immune Response Associated Genes } \\
\hline Gene & Description & FC \\
\hline GNG2 & G protein subunit gamma & 1.35 \\
\hline$V W F$ & Maintains hemostasis, promotes adhesion of platelets to sites of vascular injury & 1.34 \\
\hline PSMD10 & Regulates 26S proteasome, p53-independent apoptosis and NFkB & 1.34 \\
\hline$P P P 2 C B$ & Serine/threonine phosphatase, implicated in negative control of cell growth and division & 1.34 \\
\hline PSMD6 & Subunit of $26 \mathrm{~S}$ proteasome which co-localizes with DNA damage, degrades ubiquiniated proteins & 1.33 \\
\hline SEC61A1 & Crucial role in insertion of membrane and secretory proteins in to endoplasmic reticulum & 1.33 \\
\hline CEBPA & Coordinates proliferation and differentiation of myeloid progenitors & 1.32 \\
\hline PIK3CB & $\begin{array}{l}\text { Catalytic sub-unit of Phosphoinositide 3-kinase (PI3K), activation of signaling cascades involved in cell } \\
\text { growth, survival, and proliferation }\end{array}$ & 1.32 \\
\hline AP3B1 & $\begin{array}{l}\text { Subunit of adaptor protein complex, target cargos into vesicles for delivery into neurites and } \\
\text { nerve terminals }\end{array}$ & 1.31 \\
\hline HLA-DMA & Prepares MHCII peptide binding site for antigen binding & 1.30 \\
\hline$A V P$ & Antidiuretic action in kidney, vasoconstriction & 1.30 \\
\hline MAPK11 & p38 MAPK, mediates activation of cellular response to pro-inflammatory cytokines & 0.75 \\
\hline ACTN1 & F-actin cross-linking protein, anchors actin to intracellular structures & 0.75 \\
\hline ELMO1 & Involved in cytoskeletal rearrangements needed of phagocytosis of apoptotic cells & 0.74 \\
\hline PSMD13 & Subunit of $19 \mathrm{~S}$ regulator of the $26 \mathrm{~S}$ proteasome. & 0.74 \\
\hline TRAP1 & TNF-receptor associated protein, maintains mitochondrial function & 0.69 \\
\hline$L P L$ & $\begin{array}{l}\text { Lipoprotein lipase, hydrolysis of triglycerides in circulating chylomicrons and very low density } \\
\text { lipoprotein (VLDL) }\end{array}$ & 0.65 \\
\hline CYCS & $\begin{array}{l}\text { Cytochrome } \mathrm{C} \text {, election carrier in mitochondrial election transport chain, initiates apoptosis when } \\
\text { released from mitochondria }\end{array}$ & 0.64 \\
\hline TIAM1 & $\begin{array}{l}\text { Connects extracellular signals to cytoskeletal activities, activates Ras-related C3 botulinum toxin } \\
\text { substrate } 1 \text { (RAC1), Cell division control protein } 42 \text { homolog (CDC42) }\end{array}$ & 0.64 \\
\hline ISG15 & $\begin{array}{l}\text { Important for innate immune response against virus, inhibits HIV viral budding. Secreted } \\
\text { interferon-stimulated gene } 15 \text { (ISG15) induces natural killer cell proliferation, neutrophil chemotaxis, } \\
\text { induces interferon-gamma (IFN } \gamma \text { ). }\end{array}$ & 0.63 \\
\hline CEBPB & Transcription factor that regulates immune and inflammatory responses & 0.59 \\
\hline$R Y R 1$ & Ryanodine receptor, mediates release of calcium from intracellular stores & 0.57 \\
\hline HSPA1B & $\begin{array}{l}\text { Member of heat shock protein } 70 \text { family, stabilizes proteins against aggregation and mediates folding of } \\
\text { new proteins }\end{array}$ & 0.53 \\
\hline
\end{tabular}

Of the development process networks, three were involved in neurogenesis, specifically, "neurogenesis-axonal guidance", "neurogenesis—synaptogenesis", and "neurogenesis-general", while five were involved in more general development processes, "Epithelial-mesenchymal Transition (EMT) regulation of epithelial-to-mesenchymal transition", "hedgehog signaling", "hemopoiesis, erythropoietin pathway", "melanocyte development and pigmentation", and "skeletal muscle development". Twenty-eight of the neurogenesis genes were up-regulated and sixteen were down-regulated. Among the up-regulated genes were those involved in formation of new neurons and glial cells (e.g., NEUROD1, OMG, PAFAH1B1, NHLH1, ITM2B, ZIC2 and OLIG2). However, the down-regulated genes also included genes involved in cell differentiation, axon guidance, and synapse formation (e.g., PLXNA1, NRXN3, UNC5A, PSD95, NDP, NRG4 and SOX8). These changes in development genes led us to hypothesize that alcohol and SIV infection in combination could affect neurogenesis in the hippocampus, which could in turn explain the cognitive deficits seen in our previous studies [8]. To explore this possibility, we utilized an in vitro model to examine the combined effect of alcohol (EtOH) and the HIV protein Tat on NPC differentiation.

\subsection{EtOH Treatment Alters NPC Differentiation in the Presence or Absence of HIV Tat}

NPCs were cultured in the presence of EtOH, Tat, or combination of EtOH/Tat for five days, after which the cells were fixed and expression of neuronal, astrocytic, and NPC-specific proteins were determined by immunostaining. Representative images of NPCs immunostained for neurons, astrocytes, and neural progenitors are shown in Figure 4A. Two-way ANOVA analysis showed a 
significant main effect of $\mathrm{EtOH}(p<0.05)$ in decreasing $\beta \mathrm{III}$ tubulin staining (Figure $4 \mathrm{C}$ ). There were no significant main effects or interactions in glial fibrillary acidic protein (GFAP) or nestin staining among any of the groups. Quantification of nuclear staining with 4',6-diamidino-2-phenylindole (DAPI) showed no differences among the groups, nor was there a difference in active caspase-3 staining. Together, these DAPI and caspase- 3 data indicate that the decrease in $\beta$ III tubulin staining was not the result of changes in neuronal survival. We then quantified the gene expression of tubulin, beta 3 class III (Tubb3) to determine if $\mathrm{EtOH}$ inhibited $\beta$ III tubulin at the transcriptional level. Surprisingly, there was a small but significant main effect of Tat on Tubb3 messenger ribonucleic acid (mRNA) expression, indicating that Tat affects the system pre-translationally and EtOH affects the system post-translationally (Figure 5A). The mRNA expression of several inflammatory genes detected in the SIV-infected macaque microarray data, along with several inflammatory cytokines implicated in HAND, were determined in NPCs. No significant differences in expression were seen in $H 2-k 1$ (histocompatibility 2, K1, K region, murine equivalent of major histocompatibility class (MHC) I genes detected in microarray) or tumor necrosis factor receptor 1a (Tnfrs1a). Expression of pro-inflammatory cytokines Tnf, C-C motif chemokine ligand 2 (Ccl2), and interferon gamma (Ifng) was below the limit of detection for all groups.
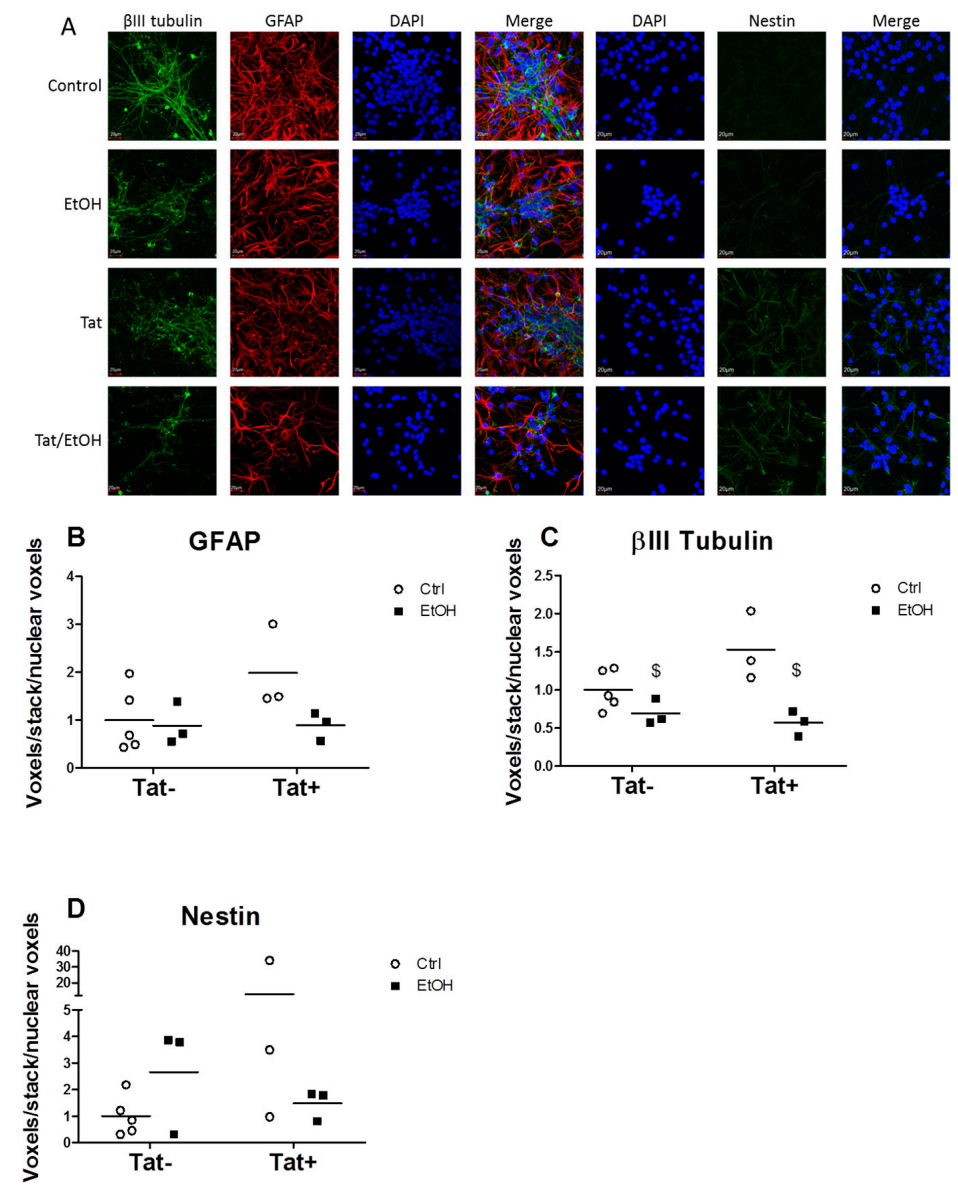

Figure 4. Panel (A) shows representative images from embryonic mouse neural progenitor cells (NPCs) treated with ethanol $(\mathrm{EtOH})$ and/or trans-activator of transcription (Tat) on day one of proliferation and during four days of differentiation. Control staining is shown in the first row, EtOH in the second row, Tat in the third row, and Tat/EtOH in the fourth row. Quantification of immunofluorescence for each marker ( $\beta$ III tubulin for neurons, glial fibrillary acidic protein (GFAP) for astrocytes, and nestin for neural progenitors) is shown in panels (B-D). Each symbol represents one experimental well. $N=5$ for the control group and $n=3$ for the experimental groups. Bar indicates the mean of each group. $\$$ indicates main effect of alcohol $(p<0.05)$ by two-way ANOVA. 


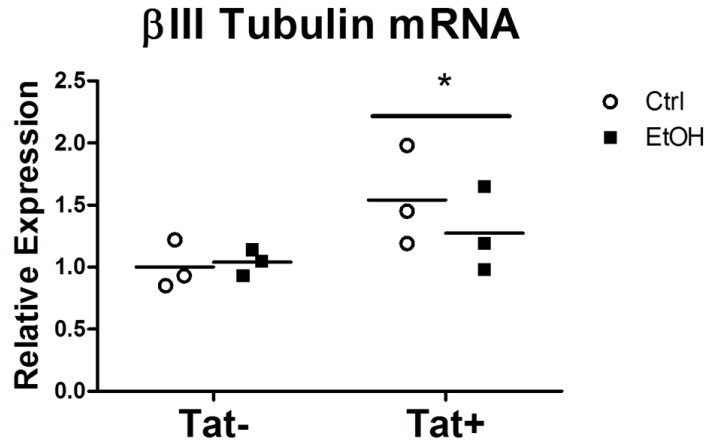

Figure 5. Relative $\beta$ III tubulin messenger ribonucleic acid (mRNA) expression in control (Ctrl) and EtOH treated NPCs with or without Tat. The solid line indicates the mean of each group. Data were analyzed by two-way ANOVA. $N=3$ per group, ${ }^{*}$ indicates $p<0.05$ in Tat+ vs Tat-.

\section{Discussion}

We examined the hippocampal gene expression profile of CBA/SIV + macaques using microarray analysis and compared it with that of SUC/SIV+ macaques. The microarray results indicated there was differential expression of the genes involved in inflammation, immune response, development, cytoskeleton, and cell adhesion processes. We interpreted these results in the context of published findings indicating a relationship between increased expression of inflammation and immune response genes resulting in decreased neurogenesis, and impaired neurogenesis resulting in cognitive deficits [22-27]. From this framework, we then hypothesized that these changes in gene expression could indicate impaired neurogenesis resulting from the combination of alcohol and SIV. We then performed in vitro studies using isolated NPCs to test the hypothesis that $\mathrm{EtOH}$ and/or HIV Tat alter neurogenesis. These experiments revealed that $\mathrm{EtOH}$ treatment reduced expression of neuronal cytoskeletal protein $\beta I I I$ tubulin. These findings led us to speculate that neuroinflammation impairs neurogenesis and synaptic plasticity, which may be potential mechanisms by which CBA unmasks neurobehavioral deficits in SIV-infected macaques [8].

Up-regulation of both major histocompatibility class (MHC) I and II gene expression was observed in CBA/SIV+ macaques (e.g., human leukocyte antigen (HLA)-F, HLA-A, HLA-E, $H L A-D R A)$. This CBA-specific up-regulation is potentially due to increased immunoproteasome activity. Supporting this interpretation, chronic alcohol administration increases the expression of immunoproteasome subunits and catalytic activity in brain tissue [28]. Furthermore, using this same model of CBA and SIV infection, we previously reported that proteasome subunit expression is dysregulated and proteasome activity is increased in skeletal muscle of CBA/SIV+ macaques [11]. Activation of the immunoproteasome favors MHC class I antigen presentation [29]. MHC proteins present peptides to immune cells as part of the innate and adaptive immune response. MHC protein expression is upregulated in microglia and macrophages of HIV-infected brains [30] and have been found to play a role in regulating synaptic density and function [31]. We speculate that our results indicating up-regulation of MHC gene expression could contribute to decreased synaptic density and function in hippocampi of CBA/SIV+ animals. However, models investigating the effect of MHCI manipulation have found variable outcomes on synaptic structure and function. MHCI knockout models have resulted in both reduced and increased neurite outgrowth, while overexpression has both enhanced and inhibited neurite outgrowth and synaptic density [32-34]. The cellular localization of MHCI receptors (neuronal vs immune cell) would likely affect the functional outcome of the change in MHCI expression. These relationships between immune response genes and synaptic function warrant further investigation.

We detected differential expression of genes involved in the growth and development of neurons, synaptogenesis, axonogenesis, and myelination in the hippocampus of CBA/SIV+ animals. Furthermore, these changes suggest that the combined effects of CBA and SIV infection hindered 
neurogenesis. The genes identified as having a role in synaptogenesis, such as post-synaptic density 95 (DLG4), contactin 1 (CNTN1), neurexin 1 (NRXN1), synaptotagmin 11 (SYT11), synaptotagmin 4 (SYT4), synaptotagmin 7 (SYT7), syntaxin 16 (STX16), actinin alpha 1 (ACTN1), synaptotagmin 14 (SYT14) and catenin beta $1(C T N N B)$, are involved in synaptic plasticity [35]. These changes are important when considered in the context of the original goal of this exploratory study-to determine gene expression changes that could underlie cognitive impairment in CBA/SIV+ animals. Neurogenesis and synaptic plasticity in the hippocampus modulate learning and memory; impairment of neurogenesis or synaptic plasticity impairs learning and memory [20,21,36]. Neuroinflammation, a common feature of HIV infection or chronic heavy alcohol consumption [37,38], has been shown to inhibit neurogenesis [39] and synaptic plasticity [40]. Taken together, our findings, with previous reports in the literature, support our conclusion that the gene changes observed likely contribute to cognitive dysfunction in $\mathrm{CBA} / \mathrm{SIV}+$ macaques. Our results showing increased expression of immune function genes in $\mathrm{CBA} / \mathrm{SIV}+$ animals associated with alterations in nervous system development and synaptic plasticity genes are in agreement with published studies [22,24]. However, the importance of individual genes remains to be tested in vivo. The gene changes may not translate to cognitive impairments and further mechanistic experiments to determine the specific effects of the gene changes are warranted.

Our results and interpretation are based on gene expression changes in the absence of parallel cognitive measures in these animals, and can only be related to our previous findings using this model of CBA/SIV. However, microarray analysis of human brain tissue from HIV+ patients with neuropathology or cognitive impairments have revealed alterations in similar genes and cellular processes to those observed in our study. Masliah et al. [41] reported down-regulation of genes involved in transcription, ion channels/transporters, cell-cycle molecules, and neuronal cytoskeleton components along with increased expression of interferon-stimulated genes in frontal cortex isolated from HIV encephalitis (HIVE) brains compared to HIV+ brains. Moreover, Gelman et al. [42] compared the gene expression in the neostriatum, neocortex, and white matter of patients with HIVE and neurocognitive impairment (NCI) to that of HIV-patients. Those results indicate strong similarities between the changes in gene expression in HIVE brains and those reported here for brains of CBA/SIV+ animals based on increased expression of interferon signaling, antigen presentation, and complement system genes. Borjabad et al. [43] also showed that patients with HIV-associated neurocognitive disorders had enhanced expression of genes involved in antigen presentation and reduced expression of neurogenesis genes, giving further support to our results. The similarities in the processes found in human HIV brain tissue with neuropathology and/or cognitive impairment support our conclusion that alterations in immune processes/inflammation and neurogenesis in the CBA/SIV+ macaques could contribute to cognitive deficits.

The findings from the microarray suggesting the involvement of processes related to neuroinflammation and neurogenesis led us to explore the functional consequences of combined exposure to alcohol and HIV proteins in an in vitro model of neurogenesis. We used embryonic murine NPCs to model neurogenesis occurring in the adult hippocampus. This model allows for studying the early stages of neurogenesis in which NPCs commit to a mature astrocytes or neurons. Others have used a similar model to determine the effects of EtOH or Tat on neurosphere growth, as well as NPC proliferation and differentiation [44-46]. Our choice of $50 \mathrm{mM}$ EtOH treatment matches what was used in previous neurogenesis studies [45] and matches the blood alcohol concentration achieved in the CBA/SIV+ macaques. Initially we aimed to validate gene expression of inflammatory receptors (H2-ka, Tnfrs1a) and pro-inflammatory cytokines ( $T n f, C c l 2, I f n g$ ) detected in the microarray in the NPC model. However, our results did not show any significant differences in their expression in response to EtOH and Tat exposure, which we believe is due to the absence of immune cells in this system, as the expression levels were low in all groups. In contrast, our results showed that Tat increased $\beta$ III tubulin at the mRNA level, while EtOH reduced the expression of $\beta$ III tubulin at the protein level. Together these results suggest that EtOH effects on $\beta I I I$ tubulin are post-translation. Future studies on this mechanism are warranted. The implications of this protein level change are relevant to cognition, 
as the expression of neuronal cytoskeleton proteins have been shown to be correlated to cognitive functioning in PLWHA. Moore et al. [47] showed that behavioral measures of cognitive functioning in humans correlated with the amount of immunohistochemical staining of the neuronal cytoskeletal protein microtubule-associated protein 2 (MAP2). The alteration of $\beta \mathrm{III}$ tubulin expression with EtOH and Tat treatment indicates the functional relevance of the changes in neurogenic and synaptogenesis genes detected CBA/SIV+.

In summary, the results of this study show that CBA administration in SIV-infected macaques results in hippocampal up-regulation of genes involved in immune function and dysregulated expression of genes involved in neurogenesis. Similar patterns of gene expression are seen in brains of patients with HIVE and NCI [42], which we speculate suggests that over-activation of immune processes underlies the impairment of neurodevelopment. This is supported by the demonstrated capacity of inflammation to impair neurogenesis [23,39]. Thus, the results of this study support the hypothesis that inflammation-driven deficits in neurogenesis are a potential mechanism by which alcohol contributes to cognitive impairment in SIV-infected macaques. We recognize that involvement of several processes other than inflammation and neurogenesis were suggested by the microarray, including cytoskeleton related functions. These other processes may be important in contributing to cognitive deficits. There are limitations to our study, including the small number of animals in each group. However, this was an exploratory study with the goal of identifying potential mechanisms for further study, which we believe was accomplished. The timing at which gene changes were observed (19 months of CBA administration and 16 months of SIV infection) does not necessarily reflect time-dependent changes. Analysis at distinct time points would have provided valuable insight into the plasticity of the differential gene expression patterns observed in CBA/SIV+. It is important to note that the cell culture model used here does not contain all the cell types that would be found in vivo. The lack of microglia and infiltrating immune cells may account for the lack of inflammatory response in vitro. This was an exploratory study, and we believe that the Tat dose selected allowed us to investigate its effect on NPCs during growth and development. Others have used $200 \mathrm{ng} / \mathrm{mL}$ for neurogenesis experiments [46], and up to $1400 \mathrm{ng} / \mathrm{mL}$ to elicit inflammatory responses from astrocytes or produce neurotoxicity in culture $[48,49]$. The rich data set identifying genes and relevant biological processes should provide groundwork for future studies exploring time course, reversibility, and contribution of their changes to overall neurobehavioral dysfunction.

\section{Materials and Methods}

\subsection{Animals}

All experiments were approved by the Institutional Animal Care and Use Committee (codes 2522 and 3310) at both Tulane National Primate Research Center (TNPRC) in Covington, LA, and Louisiana State University Health Sciences Center in New Orleans, LA. All experiments adhered to the National Institutes of Health Guidelines for the Care and Use of Experimental Animals [50]. Animals had been used in previously published studies and the experimental procedures for alcohol administration and SIV inoculation are described in detail in those publications [10,51,52]. Briefly, young adult, male Macaca mulatta from two experimental groups; sucrose-administered SIV-infected (SUC/SIV+; $n=2$ ), and CBA SIV-infected (CBA/SIV $+; n=2)$ were used in the study. SIV+ animals were all from the same experimental cohort and underwent all experimental procedures during the same time period. Animals were six years of age at necropsy.

CBA administration consisted of ethanol (30\%) delivery via an indwelling gastric catheter providing a mean of $13-14 \mathrm{~g} / \mathrm{kg}$ /week beginning three months prior to SIV inoculation and continuing throughout the study as previously described [10,51]. CBA administration was initiated prior to SIV infection to model risky alcohol use leading to HIV infection, as binge alcohol increases the risk of contracting HIV [53-56]. This protocol of alcohol administration results in blood alcohol concentrations ranging from 50 to $60 \mathrm{mmol} / \mathrm{L}$, similar to that achieved with heavy alcohol consumption in humans [57]. 
The protocol of alcohol administration models a chronic binge-like alcohol intake, a frequent pattern of heavy alcohol consumption [58]. Following three months of CBA administration, animals were inoculated intravenously with 10,000 times the infective dose (ID 50 ) of SIVmac251 (provided by Preston Marx, TNPRC). The progression of SIV disease was monitored throughout the study using clinical, biochemical, immunological, and plasma viral kinetic analysis as reported elsewhere [10,51,52]. Sixteen months post-SIV inoculation, animals were euthanized in accordance with the Panel on Euthanasia of the American Veterinary Medical Association. Whole brains were removed during necropsy, frozen in liquid nitrogen, and stored at $-80{ }^{\circ} \mathrm{C}$ until analysis.

\subsection{Hippocampus and RNA Isolation}

Hippocampal brain tissue was isolated by dissecting tissue from a frozen hemi-brain. First, the intersection of the superior and inferior arcuate sulcus and the arcuate sulcus spur was located. Twenty millimeters caudal from that landmark, a coronal slice was made to reveal the hippocampus (bregma-20.00 $\mathrm{mm}$ ) [59]. We then removed the hippocampus sample with a surgical scalpel.

RNA was extracted from frozen samples using TRIZOL reagent as recommended by the manufacturer (Invitrogen, Carlsbad, CA, USA). 200 ng of RNA were used to make biotinylated complementary RNA (cRNA) using the Illumina TotalPrep RNA Amplification Kit (Ambion, Austin, TX, USA), and hybridized for $14 \mathrm{~h}$ at $58^{\circ}$ to HumanWG6_v3 chips, following manufacturer's instructions (Illumina, San Diego, CA, USA). The arrays were scanned with the BeadArray Reader (Illumina, San Diego, CA, USA) and analyzed with GenomeStudio software (Illumina).

\subsection{Cerebrospinal Fluid (CSF) Collection}

CSF collection took place seven months after SIV inoculation. Macaques were anesthetized and a 22-guage needle was inserted into the fourth ventricle. CSF flowed freely from the needle hub and droplets collected until a volume of 0.5 to $1.0 \mathrm{~mL}$ was reached. CSF was stored at $-80^{\circ} \mathrm{C}$ until use.

\subsection{Viral Load Quantification}

For quantification of viral loads, DNA and RNA were extracted from the frozen hippocampal tissue and CSF using DNeasy mini kit and RNeasy Universal mini kit following the manufacturer's instructions (Qiagen, Valencia, CA, USA). SIV DNA and RNA levels were quantified with a TaqMan (Life Technologies, Carlsbad, CA, USA) quantitative PCR assay (qPCR) that targets a conserved region in SIV gag as detailed previously [60]. Briefly, the quantity of SIV DNA was measured in duplicate aliquots of DNA and normalized to cell number using a qPCR assay that targets a single copy gene (Rnase P). Copies of SIV RNA were determined by adding approximately $100 \mathrm{ng}$ of sample RNA to duplicate reverse-transcription qPCR (rt-qPCR) amplification assays. The average SIV RNA copy number was determined and normalized to micrograms of RNA (for brain tissue) or mL CSF utilizing a rt-qPCR assay that targets the housekeeping gene ribrosomal protein S13 (RPS13), with validated Taq-Man primers and probe as described [61]. The limit of detection in these assays is 100 copies SIV DNA $/ 1 \times 10^{6}$ cells and 50 copies SIV RNA per microgram RNA.

\subsection{Microarray Data Analysis}

For Illumina chips, the background noise was eliminated by determining the level of hybridization of irrelevant probes. The signals were normalized assuming a similar distribution of transcript abundance in all the samples [62]. A differential analysis of gene expression was done using the level of expression in the SUC/SIV+ samples as a reference. A list of differentially expressed genes for CBA/SIV+ animals was generated by finding the top one percent of up-regulated genes and top one percent of down-regulated genes based on the frequency of fold-change values. This corresponded to the inclusion of genes that were increased or decreased 1.3 fold in CBA/SIV+ compared to SUC/SIV+, as used by other investigators [63,64]. The list of differentially expressed genes was further filtered by removing any genes for which there was overlap of their raw expression values between animals 
in the two groups. Thus, the final gene list contained the top one percent of up-regulated and top one percent of down-regulated genes in which both CBA/SIV+ animals had increased or decreased expression compared to both SUC/SIV+ animals (Figure 1A). In order to determine the biological significance and function of the differentially expressed genes, we used MetaCore from Thomson Reuters (Philadelphia, PA, USA) to determine the Process Networks of the differentially expressed genes [60]. The Process Networks indicate the cellular functions regulated by the input list of genes. We used two quantification strategies to analyze the MetaCore results in order to account for the multiple potential interpretations of these data. In the first analysis, we identified the most significantly enriched processes in which the differentially expressed genes are involved. In the second analysis, we quantified the top 100 processes of the differentially expressed genes. These analyses allowed us to determine the specific functions and general processes that are most affected by the combination of CBA and SIV infection. GeneCards (version 3.12.256, www.genecards.org, Rehovot, Israel) [65] database was used for determining the function of individual genes/proteins.

\subsection{NPC Isolation and Culture}

Using a standard technique [66], NPCs were isolated from pooled male and female mouse brains at embryonic day 17.5. After dissociation by gentle trypsinization (TrypleE Express, Gibco, Waltham, MA, USA) and pipetting with a fire-polished glass Pasteur pipette, single cell suspension neural cells were plated on non-adherent cell culture dishes at densities ranging from $1 \times 10^{2}$ to $1 \times 10^{5} \mathrm{cells} / \mathrm{cm}^{2}$. The culture medium used to support proliferation of neural progenitors and the formation of primary neurospheres consisted of NeuroBasal Medium (Gibco), B27 supplement (Gibco), N2 supplement (Gibco), Heparin (2 ng/mL), epidermal growth factor (EGF) $(20 \mathrm{ng} / \mathrm{mL}$, Invitrogen, Waltham, MA, USA), basic fibroblast growth factor (bFGF) $(20 \mathrm{ng} / \mathrm{mL}$, Invitrogen), and Glutamax (Gibco). Following three days of continuous growth, primary neurospheres were dissociated to single cell suspension and plated at low density $\left(5.0 \times 10^{5}\right.$ cells $\left./ \mathrm{cm}^{2}\right)$ on non-adherent cell culture dishes in the same medium. The resulting secondary neurospheres were treated with or without $\mathrm{EtOH}(50 \mathrm{mM})$ and with or without Tat $(200 \mathrm{ng} / \mathrm{mL})$, for $24 \mathrm{~h}$. The EtOH concentration was selected to match that achieved in vivo with the intragastric alcohol delivery protocol in the macaques. Tat concentrations were based on [46]. These non-adherent cells were then transferred to poly-D-lysine/Laminin coated glass chambers slides and allowed to differentiate in NeuroBasal medium containing B27 and N2 supplements, heparin, and Glutamax. During the differentiation process, the neurospheres were treated with $\mathrm{EtOH}(50 \mathrm{mM})$, Tat $(200 \mathrm{ng} / \mathrm{mL})$ or both on the first day of differentiation and EtOH $(50 \mathrm{mM})$, Tat $(125 \mathrm{ng} / \mathrm{mL})$, or both on the third day of differentiation. The lower concentration of Tat on the third day was used to avoid overt cell death as we sought to determine how the treatments would alter cell development. Cells were fixed on day four of differentiation in the same chamber slides in which they were differentiated using $4 \%$ formaldehyde in phosphate buffered saline. Fixed cells were used for immunofluorescent analysis ( $n=5$ for controls or 3 for experimental groups); unfixed cells were pelleted and frozen at $-80{ }^{\circ} \mathrm{C}$ until use in Western Blot or qPCR assays ( $n=3$ per group).

\subsection{NPC RNA Isolation and $q P C R$}

NPC differentiation was determined by measuring the expression of the cytoskeletal protein nestin. The nestin expression decreases as the cells differentiate into neurons or astrocytes. New neurons express $\beta$ III tubulin and astrocytes express glial fibrillary acidic protein (GFAP). Evaluating the expression of each of these proteins allowed us to determine patterns of NPC differentiation into mature cell types. Measuring $\beta I I I$ tubulin and GFAP expression has been used by others to model the effects of HIV or alcohol alone on neurogenesis [44,45,67]. We utilized the RNeasy Mini Kit (Qiagen) to extract RNA from cell pellets. RNA purity and concentration was determined using spectrophotometry (NanoDrop, Wilmington, DE, USA). We reverse transcribed isolated RNA to complimentary DNA (cDNA) using QuantiTect Reverse Transcription Kit (Qiagen. Tubb3 (NM_023279.2), Gfap (NM_010277.3), nestin (Nes) (NM_016701.3), H2-ka (NM_001001892.2), Tnfrs1a (NM_011609.4), Tnf 
(NM_013693.3), Ccl2 (NM_011333.3), Ifng (NM_008337.4) and Rps13 (NM_026533.3) primers were purchased from Qiagen. See Table 1 for RefSeq Accession numbers. The relative gene expression was quantified using the $\Delta \Delta \mathrm{Ct}$ method with Rps13 as the housekeeping gene.

\subsection{NPC Immunocytochemistry}

Slides were analyzed by immunofluorescent labeling to discriminate the content of neural cell types with anti- $\beta$ III tubulin (1:100, Biolegend, San Diego, CA, USA), anti-GFAP (1:100, Millipore, Billerica, MA, USA), and anti-nestin (1:100, Millipore, Billerica, MA, USA) antibodies diluted in $1 \%$ bovine serum albumin plus $0.02 \%$ Triton $X-100$. Secondary antibodies were goat anti-rabbit fluorescein- (Life Technologies, Carlsbad, CA, USA) or goat anti-mouse rodamine-conjugated (Pierce, Waltham, MA, USA) at 1:500 dilution in $5 \%$ bovine serum albumin plus $0.02 \%$ Triton X-100. Images were taken at 600x magnification using an Olympus Fluoview FV1000 Biological Laser Scanning Microscope equipped with a multi-line Argon laser $(458 \mathrm{~nm}, 488 \mathrm{~nm}, 515 \mathrm{~nm})$ and diode lasers $(405 \mathrm{~nm}$, $559 \mathrm{~nm}, 635 \mathrm{~nm}$, Olympus of America, Center Valley, PA, USA). Imaging was done at 8 microseconds per pixel, 0.331 micrometers per pixel, and images were $640 \times 640$ pixels. Lasers were used at the following powers: $405 \mathrm{~nm}(20.0 \%), 488 \mathrm{~nm}(10.0 \%)$, and $559 \mathrm{~nm}(20.0 \%)$. Images were all captured using a 60x oil objective at $1 \mathrm{x}$ zoom. Software used was FV10-ASW version 4.00.03.04. Images (five to ten per slide) were all collected and quantified using the same settings. Z-stack images were taken from the top to the bottom of the cells within the view. Quantification of immunolabeling was accomplished using SlideBook 5.0 image analysis software version 5.0.0.19 (3i, Denver, CO, USA). MD performed the image acquisition and JM performed the image analysis. Identical thresholds for positive staining were applied to all images to determine the number of positively stained voxels. The number of positively stained voxels was normalized by both the thickness of the z-plane and by the number of nuclear voxels to account for variations in image thickness and cell number. Experimental groups are expressed as fold-change relative to control group.

\subsection{Data Analysis}

We used two-way ANOVA with Bonferroni post-hoc tests to analyze immunohistochemistry data obtained from the neural progenitor cell cultures. A chi-square test was used to compare the number of up- or down-regulated genes in process networks using the percentage of up- or down-regulated genes among all differentially expressed genes as the expected frequency. Statistical analysis was performed using GraphPad Prism (version 5.04 for Windows, GraphPad Software, La Jolla, CA, USA) and GraphPad QuickCalcs (web site: http://www.graphpad.com/quickcalcs/chisquared2/, accessed on 9 May 2016).

Acknowledgments: The authors are grateful for the scientific contributions of Drs. Liz Simon, Scott Edwards, Hui-Yi Lin, Don Mercante and the Comprehensive Alcohol Research Core. We are grateful for measurements of circulating and tissue viral load analysis by Dr. Angela Amedee, and for the technical contributions of Nedra Lacour. This work was supported by the National Institute of Alcoholism and Alcohol Abuse at the National Institute of Health (grant No. T32 AA07577 to Patricia Molina., No. P60 AA09803 to Patricia Molina, No. F31 AA024365 to John Maxi.]), the National Institute of General Medical Sciences at the Nation Institute of Health (grant number P20 GM103501 subproject \#2, No. P30 GM114732, No. U54 GM104940-01 to Jovanny Zabaleta), The National Institute on Minority Health and Health Disparities (grant No. P20 MD004817 and No. U54 MD008176-01 to Jovanny Zabaleta) and No. RR000164.

Author Contributions: J.M., M.D., K.R., G.J., S.N., P.W., F.P. and P.M. conceived and designed the experiments; J.M. and M.D. performed the experiments; J.M. and J.Z. analyzed the data; J.M. and P.M. wrote the paper. All authors have read and approved the final draft of the manuscript.

Conflicts of Interest: The authors declare no conflict of interest. The funding sponsors had no role in the design of the study; in the collection, analyses, nor in the interpretation of data; writing of the manuscript or the decision to publish the results. 


\section{References}

1. Heaton, R.K.; Franklin, D.R.; Ellis, R.J.; McCutchan, J.A.; Letendre, S.L.; Leblanc, S.; Corkran, S.H.; Duarte, N.A.; Clifford, D.B.; Woods, S.P.; et al. HIV-associated neurocognitive disorders before and during the era of combination antiretroviral therapy: Differences in rates, nature, and predictors. J. Neurovirol. 2011, 17, 3-16. [CrossRef] [PubMed]

2. Grant, B.F.; Goldstein, R.B.; Saha, T.D.; Chou, S.P.; Jung, J.; Zhang, H.; Pickering, R.P.; Ruan, W.J.; Smith, S.M.; Huang, B.; et al. Epidemiology of DSM-5 Alcohol Use Disorder: Results From the National Epidemiologic Survey on Alcohol and Related Conditions III. JAMA Psychiatry 2015, 72, 757-766. [CrossRef] [PubMed]

3. Joska, J.A.; Fincham, D.S.; Stein, D.J.; Paul, R.H.; Seedat, S. Clinical correlates of HIV-associated neurocognitive disorders in South Africa. AIDS Behav. 2010, 14, 371-378. [CrossRef] [PubMed]

4. Gongvatana, A.; Morgan, E.E.; Iudicello, J.E.; Letendre, S.L.; Grant, I.; Woods, S.P.; The HIV Neurobehavioral Research Program (HNRP) Group. A history of alcohol dependence augments HIV-associated neurocognitive deficits in persons aged 60 and older. J Neurovirol. 2014, 20, 505-513. [CrossRef] [PubMed]

5. Molina, P.E.; Bagby, G.J.; Nelson, S. Biomedical consequences of alcohol use disorders in the HIV-infected host. Curr. HIV Res. 2014, 12, 265-275. [CrossRef] [PubMed]

6. Woods, S.P.; Moore, D.J.; Weber, E.; Grant, I. Cognitive neuropsychology of HIV-associated neurocognitive disorders. Neuropsychol. Rev. 2009, 19, 152-168. [CrossRef] [PubMed]

7. Heaton, R.K.; Clifford, D.B.; Franklin, D.R., Jr.; Woods, S.P.; Ake, C.; Vaida, F.; Ellis, R.J.; Letendre, S.L.; Marcotte, T.D.; Atkinson, J.H.; et al. HIV-associated neurocognitive disorders persist in the era of potent antiretroviral therapy: CHARTER Study. Neurology 2010, 75, 2087-2096. [CrossRef] [PubMed]

8. Winsauer, P.J.; Moerschbaecher, J.M.; Brauner, I.N.; Purcell, J.E.; Lancaster, J.R., Jr.; Bagby, G.J.; Nelson, S. Alcohol unmasks simian immunodeficiency virus-induced cognitive impairments in rhesus monkeys. Alcohol Clin. Exp. Res. 2002, 26, 1846-1857. [CrossRef] [PubMed]

9. Bagby, G.J.; Zhang, P.; Purcell, J.E.; Didier, P.J.; Nelson, S. Chronic binge ethanol consumption accelerates progression of simian immunodeficiency virus disease. Alcohol Clin. Exp. Res. 2006, 30, 1781-1790. [CrossRef] [PubMed]

10. Molina, P.E.; Lang, C.H.; McNurlan, M.; Bagby, G.J.; Nelson, S. Chronic alcohol accentuates simian acquired immunodeficiency syndrome-associated wasting. Alcohol Clin. Exp. Res. 2008, 32, 138-147. [CrossRef] [PubMed]

11. LeCapitaine, N.J.; Wang, Z.Q.; Dufour, J.P.; Potter, B.J.; Bagby, G.J.; Nelson, S.; Cefalu, W.T.; Molina, P.E. Disrupted anabolic and catabolic processes may contribute to alcohol-accentuated SAIDS-associated wasting. J. Infect. Dis. 2011, 204, 1246-1255. [CrossRef] [PubMed]

12. Dodd, T.; Simon, L.; LeCapitaine, N.J.; Zabaleta, J.; Mussell, J.; Berner, P.; Ford, S.; Dufour, J.; Bagby, G.J.; Nelson, S.; et al. Chronic binge alcohol administration accentuates expression of pro-fibrotic and inflammatory genes in the skeletal muscle of simian immunodeficiency virus-infected macaques. Alcohol Clin. Exp. Res. 2014, 38, 2697-2706. [CrossRef] [PubMed]

13. Chanraud, S.; Martelli, C.; Delain, F.; Kostogianni, N.; Douaud, G.; Aubin, H.J.; Reynaud, M.; Martinot, J.L. Brain morphometry and cognitive performance in detoxified alcohol-dependents with preserved psychosocial functioning. Neuropsychopharmacology 2007, 32, 429-438. [CrossRef] [PubMed]

14. Gongvatana, A.; Correia, S.; Dunsiger, S.; Gauthier, L.; Devlin, K.N.; Ross, S.; Navia, B.; Tashima, K.T.; DeLaMonte, S.; Cohen, R.A. Plasma cytokine levels are related to brain volumes in HIV-infected individuals. J. Neuroimmune Pharmacol. 2014, 9, 740-750. [CrossRef] [PubMed]

15. Ketchum, M.J.; Weyand, T.G.; Weed, P.F.; Winsauer, P.J. Learning by subtraction: Hippocampal activity and effects of ethanol during the acquisition and performance of response sequences. Hippocampus 2016, 26, 601-622. [CrossRef] [PubMed]

16. Mankowski, J.L.; Queen, S.E.; Clements, J.E.; Zink, M.C. Cerebrospinal fluid markers that predict SIV CNS disease. J. Neuroimmunol. 2004, 157, 66-70. [CrossRef] [PubMed]

17. Zink, M.C.; Coleman, G.D.; Mankowski, J.L.; Adams, R.J.; Tarwater, P.M.; Fox, K.; Clements, J.E. Increased macrophage chemoattractant protein-1 in cerebrospinal fluid precedes and predicts simian immunodeficiency virus encephalitis. J. Infect. Dis. 2001, 184, 1015-1021. [CrossRef] [PubMed] 
18. Zink, M.C.; Suryanarayana, K.; Mankowski, J.L.; Shen, A.; Piatak, M., Jr.; Spelman, J.P.; Carter, D.L.; Adams, R.J.; Lifson, J.D.; Clements, J.E. High viral load in the cerebrospinal fluid and brain correlates with severity of simian immunodeficiency virus encephalitis. J. Virol. 1999, 73, 10480-10488. [PubMed]

19. Crews, F.T.; Sarkar, D.K.; Qin, L.; Zou, J.; Boyadjieva, N.; Vetreno, R.P. Neuroimmune Function and the Consequences of Alcohol Exposure. Alcohol Res. 2015, 37, 331-351. [PubMed]

20. Zhao, C.; Den, W.; Gage, F.H. Mechanisms and functional implications of adult neurogenesis. Cell 2008, 132, 645-660. [CrossRef] [PubMed]

21. Marin-Burgin, A.; Schinder, A.F. Requirement of adult-born neurons for hippocampus-dependent learning. Behav. Brain. Res. 2012, 227, 391-399. [CrossRef] [PubMed]

22. Iosif, R.E.; Ekdahl, C.T.; Ahlenius, H.; Pronk, C.J.; Bonde, S.; Kokaia, Z.; Jacobsen, S.E.; Lindvall, O. Tumor necrosis factor receptor 1 is a negative regulator of progenitor proliferation in adult hippocampal neurogenesis. J. Neurosci. 2006, 26, 9703-9712. [CrossRef] [PubMed]

23. Chen, Z.; Palmer, T.D. Differential roles of TNFR1 and TNFR2 signaling in adult hippocampal neurogenesis. Brain Behav. Immun. 2013, 30, 45-53. [CrossRef] [PubMed]

24. Ryan, S.M.; Nolan, Y.M. Neuroinflammation negatively affects adult hippocampal neurogenesis and cognition: can exercise compensate? Neurosci. Biobehav. Rev. 2016, 61, 121-131. [CrossRef] [PubMed]

25. Winocur, G.; Wojtowicz, J.M.; Sekeres, M.; Snyder, J.S.; Wang, S. Inhibition of neurogenesis interferes with hippocampus-dependent memory function. Hippocampus 2006, 16, 296-304. [CrossRef] [PubMed]

26. Dupret, D.; Revest, J.M.; Koehl, M.; Ichas, F.; De Giorgi, F.; Costet, P.; Abrous, D.N.; Piazza, P.V. Spatial relational memory requires hippocampal adult neurogenesis. PLoS ONE 2008, 3, e1959. [CrossRef] [PubMed]

27. Snyder, J.S.; Choe, J.S.; Clifford, M.A.; Jeurling, S.I.; Hurley, P.; Brown, A.; Kamhi, J.F.; Cameron, H.A. Adult-born hippocampal neurons are more numerous, faster maturing, and more involved in behavior in rats than in mice. J. Neurosci. 2009, 29, 14484-14495. [CrossRef] [PubMed]

28. Pla, A.; Pascual, M.; Renau-Piqueras, J.; Guerri, C. TLR4 mediates the impairment of ubiquitin-proteasome and autophagy-lysosome pathways induced by ethanol treatment in brain. Cell Death Dis. 2014, 5, e1066. [CrossRef] [PubMed]

29. Angeles, A.; Fung, G.; Luo, H. Immune and non-immune functions of the immunoproteasome. Front Biosci. (Landmark Ed.) 2012, 17, 1904-1916. [CrossRef] [PubMed]

30. Tavazzi, E.; Morrison, D.; Sullivan, P.; Morgello, S.; Fischer, T. Brain inflammation is a common feature of HIV-infected patients without HIV encephalitis or productive brain infection. Curr. HIV Res. 2014, 12, 97-110. [CrossRef] [PubMed]

31. Elmer, B.M.; McAllister, A.K. Major histocompatibility complex class I proteins in brain development and plasticity. Trends Neurosci. 2012, 35, 660-670. [CrossRef] [PubMed]

32. Glynn, M.W.; Elmer, B.M.; Garay, P.A.; Liu, X.B.; Needleman, L.A.; El-Sabeawy, F.; McAllister, A.K. MHCI negatively regulates synapse density during the establishment of cortical connections. Nat. Neurosci. 2011, 14, 442-451. [CrossRef] [PubMed]

33. Bilousova, T.; Dang, H.; Xu, W.; Gustafson, S.; Jin, Y.; Wickramasinghe, L.; Won, T.; Bobarnac, G.; Middleton, B.; Tian, J.; et al. Major histocompatibility complex class I molecules modulate embryonic neuritogenesis and neuronal polarization. J. Neuroimmunol. 2012, 247, 1-8. [CrossRef] [PubMed]

34. Goddard, C.A.; Butts, D.A.; Shatz, C.J. Regulation of CNS synapses by neuronal MHC class I. Proc. Natl. Acad. Sci. USA 2007, 104, 6828-6833. [CrossRef] [PubMed]

35. Arikkath, J.; Reichardt, L.F. Cadherins and catenins at synapses: Roles in synaptogenesis and synaptic plasticity. Trends Neurosci. 2008, 31, 487-494. [CrossRef] [PubMed]

36. Fitting, S.; Ignatowska-Jankowska, B.M.; Bull, C.; Skoff, R.P.; Lichtman, A.H.; Wise, L.E.; Fox, M.A.; Su, J.; Medina, A.E.; Krahe, T.E.; et al. Synaptic dysfunction in the hippocampus accompanies learning and memory deficits in human immunodeficiency virus type-1 Tat transgenic mice. Biol. Psychiatry 2013, 73, 443-453. [CrossRef] [PubMed]

37. Roberts, E.S.; Masliah, E.; Fox, H.S. CD163 identifies a unique population of ramified microglia in HIV encephalitis (HIVE). J. Neuropathol. Exp. Neurol. 2004, 63, 1255-1264. [CrossRef] [PubMed]

38. He, J.; Crews, F.T. Increased MCP-1 and microglia in various regions of the human alcoholic brain. Exp. Neurol. 2008, 210, 349-358. [CrossRef] [PubMed]

39. Ekdahl, C.T.; Claasen, J.H.; Bonde, S.; Kokaia, Z.; Lindvall, O. Inflammation is detrimental for neurogenesis in adult brain. Proc. Natl. Acad. Sci. USA 2003, 100, 13632-13637. [CrossRef] [PubMed] 
40. Vereker, E.; O'Donnell, E.; Lynch, M.A. The inhibitory effect of interleukin-1beta on long-term potentiation is coupled with increased activity of stress-activated protein kinases. J. Neurosci. 2000, 20, 6811-6819. [PubMed]

41. Masliah, E.; Roberts, E.S.; Langford, D.; Everall, I.; Crews, L.; Adame, A.; Rockenstein, E.; Fox, H.S. Patterns of gene dysregulation in the frontal cortex of patients with HIV encephalitis. J. Neuroimmunol. 2004, 157, 163-175. [CrossRef] [PubMed]

42. Gelman, B.B.; Chen, T.; Lisinicchia, J.G.; Soukup, V.M.; Carmical, J.R.; Starkey, J.M.; Masliah, E.; Commins, D.L.; Brandt, D.; Grant, I.; et al. The National NeuroAIDS Tissue Consortium brain gene array: two types of HIV-associated neurocognitive impairment. PLoS ONE 2012, 7, e46178. [CrossRef] [PubMed]

43. Borjabad, A.; Morgello, S.; Chao, W.; Kim, S.Y.; Brooks, A.I.; Murray, J.; Potash, M.J.; Volsky, D.J. Significant effects of antiretroviral therapy on global gene expression in brain tissues of patients with HIV-1-associated neurocognitive disorders. PLoS Pathog. 2011, 7, e1002213. [CrossRef] [PubMed]

44. Mishra, M.; Taneja, M.; Malik, S.; Khalique, H.; Seth, P. Human immunodeficiency virus type 1 Tat modulates proliferation and differentiation of human neural precursor cells: Implication in NeuroAIDS. J. Neurovirol. 2010, 16, 355-367. [CrossRef] [PubMed]

45. Rashid, M.A.; Kim, H.Y. N-Docosahexaenoylethanolamine ameliorates ethanol-induced impairment of neural stem cell neurogenic differentiation. Neuropharmacology 2015, 102, 174-185. [CrossRef] [PubMed]

46. Chao, J.; Yang, L.; Yao, H.; Buch, S. Platelet-derived growth factor-BB restores HIV Tat-mediated impairment of neurogenesis: role of GSK-3beta/beta-catenin. J. Neuroimmune Pharmacol. 2014, 9, 259-268. [CrossRef] [PubMed]

47. Moore, D.J.; Masliah, E.; Rippeth, J.D.; Gonzalez, R.; Carey, C.L.; Cherner, M.; Ellis, R.J.; Achim, C.L.; Marcotte, T.D.; Heaton, R.K.; et al. Cortical and subcortical neurodegeneration is associated with HIV neurocognitive impairment. AIDS 2006, 20, 879-887. [CrossRef] [PubMed]

48. Nath, A.; Conant, K.; Chen, P.; Scott, C.; Major, E.O. Transient exposure to HIV-1 Tat protein results in cytokine production in macrophages and astrocytes. A hit and run phenomenon. J. Biol. Chem. 1999, 274, 17098-17102. [CrossRef] [PubMed]

49. Buscemi, L.; Ramonet, D.; Geiger, J.D. Human immunodeficiency virus type-1 protein Tat induces tumor necrosis factor-alpha-mediated neurotoxicity. Neurobiol. Dis. 2007, 26, 661-670. [CrossRef] [PubMed]

50. National Research Council (US) Committee for the Update of the Guide for the Care and Use of Laboratory Animals. Guide for the Care and Use of Laboratory Animals, 8th ed.; National Academies Press: Washington, DC, USA, 2011.

51. Bagby, G.J.; Stoltz, D.A.; Zhang, P.; Kolls, J.K.; Brown, J.; Bohm, R.P., Jr.; Rockar, R.; Purcell, J.; Murphey-Corb, M.; Nelson, S. The effect of chronic binge ethanol consumption on the primary stage of SIV infection in rhesus macaques. Alcohol Clin. Exp. Res. 2003, 27, 495-502. [CrossRef] [PubMed]

52. Molina, P.E.; McNurlan, M.; Rathmacher, J.; Lang, C.H.; Zambell, K.L.; Purcell, J.; Bohm, R.P.; Zhang, P.; Bagby, G.J.; Nelson, S. Chronic alcohol accentuates nutritional, metabolic, and immune alterations during asymptomatic simian immunodeficiency virus infection. Alcohol Clin. Exp. Res. 2006, 30, 2065-2078. [CrossRef] [PubMed]

53. Purcell, D.W.; Parsons, J.T.; Halkitis, P.N.; Mizuno, Y.; Woods, W.J. Substance use and sexual transmission risk behavior of HIV-positive men who have sex with men. J. Subst. Abuse 2001, 13, 185-200. [CrossRef]

54. Pandrea, I.; Happel, K.I.; Amedee, A.M.; Bagby, G.J.; Nelson, S. Alcohol's role in HIV transmission and disease progression. Alcohol Res. Health 2010, 33, 203-218. [PubMed]

55. Cook, R.L.; McGinnis, K.A.; Kraemer, K.L.; Gordon, A.J.; Conigliaro, J.; Maisto, S.A.; Samet, J.H.; Crystal, S.; Rimland, D.; Bryant, K.J.; et al. Intoxication before intercourse and risky sexual behavior in male veterans with and without human immunodeficiency virus infection. Med. Care 2006, 44, S31-S36. [CrossRef] [PubMed]

56. Stein, M.D.; Hanna, L.; Natarajan, R.; Clarke, J.; Marisi, M.; Sobota, M.; Rich, J. Alcohol use patterns predict high-risk HIV behaviors among active injection drug users. J. Subst. Abuse Treat 2000, 18, 359-363. [CrossRef]

57. Friedman, L.S. Complications associated with blood alcohol concentration following injury. Alcohol 2014, 48, 391-400. [CrossRef] [PubMed]

58. Center for Behavioral Health Statistics and Quality. Behavioral Health Trends in the United States: Results from the 2014 National Survey on Drug Use and Health; HHS Publication: Washington, DC, USA, 2015. 
59. Paxinos, G.; Huang, X.F.; Petrides, M.; Toga, A.W. The Rhesus Monkey Brain in Stereotaxic Coordinates, 2nd ed.; Elsevier Academic Press: San Diego, CA, USA, 2009; p. 163.

60. Molina, P.E.; Amedee, A.M.; LeCapitaine, N.J.; Zabaleta, J.; Mohan, M.; Winsauer, P.J.; Vande Stouwe, C.; McGoey, R.R.; Auten, M.W.; LaMotte, L.; et al. Modulation of gut-specific mechanisms by chronic delta(9)-tetrahydrocannabinol administration in male rhesus macaques infected with simian immunodeficiency virus: A systems biology analysis. AIDS Res. Hum. Retrovir. 2014, 30, 567-578. [CrossRef] [PubMed]

61. Clark-Langone, K.M.; Wu, J.Y.; Sangli, C.; Chen, A.; Snable, J.L.; Nguyen, A.; Hackett, J.R.; Baker, J.; Yothers, G.; Kim, C.; et al. Biomarker discovery for colon cancer using a 761 gene RT-PCR assay. BMC Genom. 2007, 8, 279. [CrossRef] [PubMed]

62. Workman, C.; Jensen, L.J.; Jarmer, H.; Berka, R.; Gautier, L.; Nielser, H.B.; Saxild, H.H.; Nielsen, C.; Brunak, S.; Knudsen, S. A new non-linear normalization method for reducing variability in DNA microarray experiments. Genome Biol. 2002, 3, research0048.1-research0048.16. [CrossRef] [PubMed]

63. Li, M.D.; Cao, J.; Wang, S.; Wang, J.; Sarkar, S.; Vigorito, M.; Ma, J.Z.; Chang, S.L. Transcriptome sequencing of gene expression in the brain of the HIV-1 transgenic rat. PLOS ONE 2013, 8, e59582. [CrossRef] [PubMed]

64. Nesil, T.; Cao, J.; Yang, Z.; Chang, S.L.; Li, M.D. Nicotine attenuates the effect of HIV-1 proteins on the neural circuits of working and contextual memories. Mol. Brain 2015, 8, 43. [CrossRef] [PubMed]

65. Safran, M.; Dalah, I.; Alexander, J.; Rosen, N.; Iny Stein, T.; Shmoish, M.; Nativ, N.; Bahir, I.; Doniger, T.; Krug, H.; et al. GeneCards Version 3: The human gene integrator. Database (Oxf.) 2010, 2010, baq020. [CrossRef] [PubMed]

66. Aprea, S.; Del Valle, L.; Mameli, G.; Sawaya, B.E.; Khalili, K.; Peruzzi, F. Tubulin-mediated binding of human immunodeficiency virus-1 Tat to the cytoskeleton causes proteasomal-dependent degradation of microtubule-associated protein 2 and neuronal damage. J. Neurosci. 2006, 26, 4054-4062. [CrossRef] [PubMed]

67. Vemuri, M.C.; Chetty, C.S. Alcohol impairs astrogliogenesis by stem cells in rodent neurospheres. Neurochem. Int. 2005, 47, 129-135. [CrossRef] [PubMed]

(C) 2016 by the authors; licensee MDPI, Basel, Switzerland. This article is an open access article distributed under the terms and conditions of the Creative Commons Attribution (CC-BY) license (http://creativecommons.org/licenses/by/4.0/). 